\title{
PROBLEMATIKA PENERAPAN KURIKULUM 2013 PADA LEMBAGA PENDIDIKAN ANAK USIA DINI DI KECAMATAN BULULAWANG
}

\author{
Nurias Zetya Nawang Lupi \\ Pendidik Lembaga PAUD Pelangi SPNF SKB Kabupaten Malang \\ email: Nuriaslupe10@gmail.com
}

\begin{abstract}
Abstrak : Problematika Penerapan Kurikulum 2013 Pada Lembaga Pendidikan Anak Usia Dini Di Kecamatan Bululawang. Kurikulum dipandang sebagai jantungnya sebuah program pendidikan. Kurikulum dapat dipandang sebagai strategi dan cara yang dirancang untuk mencapai tujuan pendidikan yang ditetapkan secara nasional. Seluruh pendidik dan pengelola PAUD harus memahami kerangka dan struktur kurikulum 2013 Pendidikan Anak Usia Dini agar dalam penyelenggaraan program PAUD sesuai dengan tujuan yang ditetapkan. Namun pada saat ini masih banyak lembaga pendidikan anak usia dini yang masih belum mampu mengaplikasikan kurikulum 2013 pada kegiatan pembelajarannya. Melihat hal itu peneliti tertarik untuk meneliti tentang problematika implementasi kurikulum lembaga PAUD di kec. Bululawang Kab. Malang. Penelitian ini menggunakan metode penelitian kualitatif, penelitian ini dilaksanakan selama 3 bulan, permasalahan yang di teliti mulai dari perencanaan, pelaksanaan dan evaluasi kurikulum 2013 di lembaga PAUD. Di kecamatan Bululawang Kab, Malang dalam pelaksanaan pembelajarannya masih belum banyak yang menerapkan kurikulum K13 dikarenakan kurangnya pemahan tentang kurikulum 2013. Dalam pelaksanaan kurikulum 2013 yang paling berperan besar adalah pendidik, tingkat kreativitas pendidik akan mempengaruhi pelaksaan pembelajaran yang menyenangkan untuk anak semakin kreatif guru dalam menyampaikan materi dalam proses pembelajaran, akan semakin mudah peserta didik menerima materi yang disampaikan, di situlah letak keberhasilan pelaksanaan kurikulum 2013 di lembaga PAUD.
\end{abstract}

\section{Kata Kunci: Kurikulum, Pendidikan, Anak Usia Dini}

\begin{abstract}
The Problem of Application of Curriculum 2013 At Early Childhood Education Institution In Bululawang Subdistrict. The curriculum is seen as the heart of an educational program. The curriculum can be viewed as a strategy and means designed to achieve nationally defined educational goals. All educators and managers of the early childhood should understand the framework and structure of curriculum 2013 Early Childhood Education for the implementation of early childhood programs in accordance with the goals set. But at this time there are still many early childhood education institutions that are still not able to apply the 2013 curriculum on learning activities. Seeing that, the researcher is interested to examine the problems of implementing the curriculum of early childhood institutions in kec. Bululawang Kab. Poor. This research uses qualitative research method, this research is conducted for 3 months, the problems are in the beginning starting from planning, implementation and evaluation of curriculum 2013 in PAUD institution. In the district of Bululawang Kab, Malang in the implementation of the lesson is still not much that apply the curriculum K13 due to lack of pemahan about curriculum 2013. In the implementation of the curriculum in 2013 the most important role is educators, the level of creativity of educators will affect the implementation of learning fun for children more creative teachers in conveying materials in the learning process, the easier the learner will receive the material delivered, that's where the success of the implementation of the 2013 curriculum in PAUD institutions.
\end{abstract}

Key word: Problems of Keyword Application: Curriculum, Education, Early Child 
Kurikulum dipandang sebagai jantungnya sebuah program pendidikan. Kurikulum dapat dipandang sebagai strategi dan cara yang dirancang untuk mencapai tujuan pendidikan yang ditetapkan secara nasional. Seyogyanya kurikulum mengarah kepada pemebentukan kompetensi output pendidikan yang bagaimana yang diharapkan. Kompetensi tersebut diharapkan selaras dengan kompetensi yang dituntut sesuai dengan era atau zaman dimana anak menjalani kehidupannya. Kurikulum 2013 mengusung pada pengembangan kurikulum konstruktivisme yang lebih bersifat fleksibel dalam pelaksanaan tetapi lebih member ruang pada anak untuk mengembangkan potensi dan talentanya. Model pendekatan kurikulum tersebut berlaku dan ditetapkan di seluruh tingkat serta jenjang pendidikan sejak Pendidikan Anak Usia Dini hingga pendidikan menengah.

Kurikulum 2013 Pendidikan Anak Usia Dini sebagai jenjang paling dasar, diharapkan menjadi fundamental penyiapan peserta didik menjadi lebih siap dalam memasuki jenjang pendidikan lebih tinggi. Hal yang paling diusung dalam Kurikulum 2013 Pendidikan Anak Usia Dini adalah keterbukaan kita menerima perubahan cara berpikir, perubahan kebiasaan, perubahan sikap. Perubahan tersebut akan berimbas pada perubahan sikap, pengetahuan, dan keterampilan peserta didik. Kurikulum 2013 sesuai dengan Peraturan Pemerintah Nomor 32 Tahun 2013 tentang Perubahan Atas Peraturan Pemerintah Nomor 19 Tahun 2005 tentang Standar Nasional Pendidikan pada dasarnya penguatan terhadap kurikulum sebelumnya dan pengembangan pada aspek struktur kurikulum, proses pembelajaran dengan pendekatan saintifik, dan penilaian yang bersifat otentik.

Seluruh pendidik dan pengelola PAUD harus memahami kerangka dan struktur kurikulum 2013 Pendidikan Anak Usia Dini agar dalam penyelenggaraan program PAUD sesuai dengan tujuan yang ditetapkan. Namun pada saat ini masih banyak lembaga pendidikan anak usia dini yang masih belum mampu mengaplikasikan kurikulum 2013 pada kegiatan pembelajarannya. Melihat hal itu peneliti tertarik untuk meneliti tentang problematika implementasi kurikulum lembaga PAUD di kec. Bululawang. Ada 5 lembaga PAUD yang menjadi tempat penelitian, pemilihan lembaga paud dilaksanakan secara acak, karena beberapa sekolah di kec. Bululawang mengalami permasalahan dalam implikasi kurikulum 2013.

Undang-Undang Nomor 20 Tahun 2003 tentang Sistem Pendidikan Nasional menyebutkan bahwa kurikulum adalah seperangkat rencana dan pengaturan mengenai tujuan, isi, dan bahan pelajaran serta cara yang digunakan sebagai pedoman penyelenggaraan kegiatan pembelajaran untuk mencapai tujuan pendidikan tertentu. PAUD merupakan pendidikan yang paling fundamental karena perkembangan anak di masa selanjutnya sangat ditentukan oleh berbagai stimulasi bermakna yang diberikan sejak usia dini.

Pendidikan anak usia dini harus dipersiapkan secara terencana dan bersifat holistik agar dimasa emas perkembangan anak mendapatkan distimulasi yang utuh, sehingga mengembangkan berbagai potensi yang dimiliki anak. Salah satu upaya yang dapat dilakukan dalam rangka pengembangan potensi tersebut adalah dengan program pendidikan yang terstruktur. Salah satu komponen untuk pendidikan yang terstruktur adalah kurikulum.

Struktur Kurikulum 2013 Pendidikan Anak Usia Dini merupakan pengorganisasian Kompetensi Inti, Kompetensi Dasar, muatan pembelajaran, program pengembangan, dan beban belajar.

\section{Standar Tingkat Pencapaian Perkembangan (STPP)}

Standar Tingkat Pencapaian Perkembangan Anak merupakan kriteria minimal tentang kualifikasi perkembangan anak yang mencakup aspek nilai agama dan moral, fisik motorik, kognitif, bahasa, sosial-emosional, dan seni.

1. Nilai-nilai agama dan moral, meliputi:

Mengenal agama yang dianut, mengerjakan ibadah, berperilaku jujur, penolong, sopan, hormat, sportif, menjaga kebersihan diri dan lingkungan, mengetahui hari besar agama, dan menghormati (toleransi) agama orang lain. 
2. Fisik Motorik, meliputi:

a. Motorik Kasar: memiliki kemampuan gerakan tubuh secara terkoordinasi, lentur, seimbang, dan lincah dan mengikuti aturan.

b. Motorik Halus: memiliki kemampuan menggunakan alat untuk mengeksplorasi dan mengekspresikan diri dalam berbagai bentuk.

c. Kesehatan dan Perilaku Keselamatan: memiliki berat badan, tinggi badan, lingkar kepala sesuai usia serta memiliki kemampuan untuk berperilaku hidup bersih, sehat, dan peduli terhadap keselamatannya

3. Kognitif, meliputi:

a. Belajar dan Pemecahan Masalah: mampu memecahkan masalah sederhana dalam kehidupan seharihari dengan cara yang fleksibel dan diterima sosial dan menerapkan pengetahuan atau pengalaman dalam konteks yang baru.

b. Berfikir logis: mengenal berbagai perbedaan, klasifikasi, pola, berinisiatif, berencana, dan mengenal sebab akibat.

c. Berfikir simbolik: mengenal, menyebutkan, dan menggunakan lambang bilangan 1-10, mengenal abjad, serta mampu merepresentasikan berbagai benda dalam bentuk gambar.

4. Bahasa, meliputi:

a. Memahami (reseptif) bahasa: memahami cerita, perintah, aturan, dan menyenangi serta menghargai bacaan.

b. Mengekspresikan Bahasa: mampu bertanya, menjawab pertanyaan, berkomunikasi secara lisan, menceritakan kembali apa yang diketahui

c. Keaksaraan: memahami hubungan bentuk dan bunyi huruf, meniru bentuk huruf, serta memahami kata dalam cerita.
5. Sosial-emosional, meliputi:

a. Kesadaran diri: memperlihatkan kemampuan diri, mengenal perasaan sendiri dan mengendalikan diri, serta mampu menyesuaian diri dengan orang lain

b. Rasa Tanggung Jawab untuk Diri dan Orang lain: mengetahui hak-haknya, mentaati aturan, mengatur diri sendiri, serta bertanggung jawab atas perilakunya untuk kebaikan sesama.

c. Perilaku Prososial: mampu bermain dengan teman sebaya, memahami perasaan, merespon, berbagi, serta menghargai hak dan pendapat orang lain; bersikap kooperatif, toleran, dan berperilaku sopan.

6. Seni, meliputi: mengeksplorasi dan mengekspresikan diri, berimaginasi dengan gerakan, musik, drama, dan beragam bidang seni lainnya (seni lukis, seni rupa, kerajinan), serta mampu mengapresiasi karya seni.

\section{Kompetensi Inti}

Kompetensi Inti (KI) pada Kurikulum 2013 Pendidikan Anak Usia Dini merupakan tingkat kemampuan untuk mencapai STPP yang harus dimiliki peserta didik PAUD pada usia 6 tahun. Jadi Kompetensi Inti merupakan operasionalisasi dari STPP dalam bentuk kualitas yang harus dimiliki anak dengan berbagai kegiatan pembelajaran melalui bermain yang dilakukan di satuan PAUD. Kualitas tersebut berisi gambaran mengenai kompetensi utama yang dikelompokkan ke dalam kompetensi sikap, pengetahuan, dan keterampilan.

Secara terstruktur kompetensi inti dimaksud mencakup:

1. Kompetensi Inti-1 (KI-1) untuk kompetensi inti sikap spiritual.

2. Kompetensi Inti-2 (KI-2) untuk kompetensi inti sikap sosial.

3. Kompetensi Inti-3 (KI-3) untuk kompetensi inti pengetahuan. 
4. Kompetensi Inti-4 (KI-4) untuk kompetensi inti keterampilan.

Rumusan kualitas masing-masing kompetensi inti yang harus dimiliki peserta didik terurai pada tabel di bawah ini.

\section{Tabel 1. Kompetensi Inti}

\begin{tabular}{|c|l|}
\hline \multicolumn{2}{|c|}{ KOMPETENSI INTI } \\
\hline KI-1 & Menerima ajaran agama yang dianutnya \\
\hline KI-2 & $\begin{array}{l}\text { Memiliki perilaku hidup sehat, rasa ingin tahu, } \\
\text { kreatif dan estetis, percaya diri, disiplin, mandiri, } \\
\text { peduli, mampu bekerja sama, mampu menyesuaikan } \\
\text { diri, jujur, dan santun dalam berinteraksi dengan } \\
\text { keluarga, pendidik dan/atau pengasuh, dan teman }\end{array}$ \\
\hline KI-3 & $\begin{array}{l}\text { Mengenali diri, keluarga, teman, pendidik dan/atau } \\
\text { pengasuh, lingkungan sekitar, teknologi, seni, dan } \\
\text { budaya di rumah, tempat bermain dan satuan PAUD } \\
\text { dengan cara: mengamati dengan indra (melihat, } \\
\text { mendengar, menghidu, merasa, meraba); menanya; } \\
\text { mengumpulkan mengolah } \\
\text { informasi/mengasosiasikan,dan } \\
\text { mengkomunikasikan melalui kegiatan bermain }\end{array}$ \\
\hline KI-4 & $\begin{array}{l}\text { Menunjukkan yang diketahui, dirasakan, } \\
\text { dibutuhkan,dan dipikirkan melalui bahasa, musik, } \\
\text { gerakan, dan karya secara produktif dan kreatif, } \\
\text { serta mencerminkan perilaku anak berakhlak mulia }\end{array}$ \\
\hline
\end{tabular}

\section{Kompetensi Dasar}

Kompetensi Dasar pada Kurikulum 2013 Pendidikan Anak Usia Dini berisikan kemampuan dan muatan pembelajaran untuk suatu tema pembelajaran pada PAUD yang mengacu pada Kompetensi Inti. Kompetensi Dasar dikembangkan berdasarkan pada prinsip akumulatif, saling memperkuat dan memperkaya antar program pengembangan. Dalam merumuskan Kompetensi Dasar juga memperhatikan karakteristik peserta didik, kemampuan awal, serta ciri dari suatu program pengembangan yang hendak dikembangkan.

Kompetensi Dasar dibagi menjadi empat kelompok sesuai dengan pengelompokkan kompetensi inti sebagai berikut:

\section{Kelompok1 : Kelompok Kompetensi Dasar sikap spiritual dalam rangka menjabarkan KI-1}

Kelompok 2: Kelompok Kompetensi Dasar sikap sosial dalam rangka menjabarkan KI-2
Kelompok 3 : Kelompok Kompetensi Dasar pengetahuan dalam rangka menjabarkan KI-3
Kelompo 4 : Kelompok Kompetensi Dasar keterampilan dalam rangka menjabarkan KI-4.

\section{Indikator perkembangan}

Indikator perkembangan merupakan penanda perkembangan yang lebih spesifik dan terukur pada satu program pengembangan untuk memantau/menilai perkembangan anak. Indikator perkembangan juga merupakan gambaran minimal mengenai ciri-ciri peserta didik yang dianggap telah mencapai kemampuan dasar pada tingkatan usia tertentu. Untuk mempertegas kedudukan indikator, maka indikator perkembangan harus dipahami sebagai berikut.

1. Indikator perkembangan merupakan kontinum perkembangan dan belajar peserta didik PAUD usia lahir-6 tahun dan dijabarkan berdasarkan kelompok usia.

2. Indikator perkembangan dirumuskan berdasarkan Kompetensi Dasar (KD).

3. Indikator perkembangan untuk KD pada KI 3 dan KI 4 menjadi satu untuk memberikan pemahaman bahwa pengetahuan dan keterampilan merupakan dua hal yang menyatu.

Fungsi indikator yaitu agar lebih tepat dalam memaknai dan menggunakan indikator perkembangan, maka fungsi indikator hendaklah dipahami dengan cermat. Fungsi indikator secara lebih jauh adalah:

1. Indikator perkembangan menjadi acuan untuk memantau/menilai perkembangan anak sesuai dengan tahapan usianya,

2. Indikator perkembangan tidak dibuat untuk menjadi kegiatan pembelajaran, tetapi menjadi panduan yang digunakan pendidik dan/atau pengasuh dalam melakukan stimulasi dan observasi kemajuan perkembangan peserta didik, 
3. Indikator juga dapat:

a. Memberi inspirasi dalam mengembangkan materi pembelajaran

b. Memberi inspirasi dalam mendesain kegiatan pembelajaran

c. Memberi inspirasi dalam mengembangkan bahan ajar

Yang harus di perhatikan dalam penyusunan Kurikulum PAUD adalah sebagai berikut :

\section{Berpusat pada anak dengan mempertimbangkan potensi, bakat, minat, perkembangan, dan kebutuhan anak, termasuk kebutuhan khusus.}

1. Kurikulum menempatkan anak sebagai pusat tujuan.

2. Kurikulum yang disusun memenuhi kebutuhan pertumbuhan dan perkembangan anak sesuai dengan tingkat usia (age appropriateness), selaras dengan potensi, minat dan karakteristik termasuk kebutuhan khusus anak secara individu (individual appropriateness).

3. Kurikulum juga bersifat inklusif dengan mengakomodir kebutuhan dan perbedaan anak baik dari aspek jenis kelamin, sosial, budaya, agama, fisik, maupun psikis sehingga semua anak terfasilitasi sesuai dengan potensi masing-masing tanpa ada diskriminasi aspek apa pun. Kurikulum dirancang untuk membangun sikap spiritual dan sosial bukan menjawab tes-tes, ujian, kuis, atau pengetahuan jangka pendek lainnya. Sikap spiritual dan social yang dimaksud adalah perilaku yang mencerminkan sikap beragama, hidup sehat, rasa ingin tahu, sikap estetis, bersikap kreatif, percaya diri, sabar, mandiri, peduli, menghargai dan toleran, mampu bekerja sama, mampu menyesuaikan diri, jujur, tanggung jawab, rendah hati dan santun dalam berinteraksi dengan keluarga, teman, dan orang dewasa lainnya di lingkungan rumah, tempat bermain, dan satuan PAUD.
Memperhatikan tingkat perkembangan anak

Kurikulum disusun dengan memperhatikan kesinambungan secara vertikal (antara tujuan pendidikan nasional, tujuan lembaga, tujuan pembelajaran, metode pembelajaran) dan kesinambungan horizontal (antara tahap perkembangan anak: usia lahir 2 tahun, usia 2-4 tahun dan usia 4-6 tahun merupakan rangkaian yang saling berkesinambungan).

$\begin{aligned} & \text { Kurikulum dikembangkan secara } \\ & \text { Kontekstual }\end{aligned}$
$\begin{gathered}\text { Kurikulum disusun } \\ \text { mempertimbangkan: }\end{gathered}$

1. Karakter daerah,

2. Kondisi satuan PAUD, dan

3. Kebutuhan anak.

\section{Mencakup semua dimensi kompetensi dan program pengembangan}

\begin{tabular}{lcc}
\multicolumn{1}{c}{ Kurikulum } & PAUD & untuk \\
mengembangkan & kompetensi & sikap, \\
pengetahuan, dan & keterampilan & yang
\end{tabular} mencakup semua program pengembangan nilai agama dan moral, fi sik-motorik (motoric kasar, motorik halus, kesehatan dan perilaku keselamatan), kognitif (belajar dan pemecahan masalah, berfi kir logis, berfi kir simbolik), bahasa (memahami bahasa reseptif, mengekspresikan bahasa, keaksaraan), sosialemosional (kesadaran diri, rasa tanggungjawab untuk diri dan orang lain, perilaku prososial) dan seni (kemampuan mengeksplorasi dan mengekspresikan diri, berimajinasi dengan gerakan, musik, drama, dan beragam bidang seni lainnya).

\section{Mempertimbangkan cara anak belajar}

Kurikulum mengakomodasi pelaksanaan pembelajaran yang memungkinkan anak membentuk pengalaman belajar dengan cara belajar anak. Anak belajar mulai dari dirinya kemudian keluar dirinya, dari konkrit ke abstrak, sederhana ke kompleks, mudah ke sulit yang dilakukan dengan cara melakukannya sendiri (hands on experience). 


\section{Holistik - integratif}

Kurikulum mengembangkan semua aspek perkembangan secara seimbang melalui layanan pendidikan, kesehatan, gizi, pengasuhan, kesejahteraan ataupun layanan perlindungan anak. Layanan pedagogis berfokus pada stimulasi perkembangan anak terutama pada stimulasi perkembangan mentalintelektual dan sosialemosional

\section{Belajar melalui bermain}

Proses membangun pengalaman bersifat aktif. Anak terlibat langsung dalam kegiatan bermain yang menyenangkan. Selama bermain anak menggunakan ide-ide baru mereka,belajar mengambil keputusan, dan memecahkan masalah sederhana.

\section{Memberi pengalaman belajar}

Penyusunan kurikulum memberikan pengalaman belajar anak tentang berbagai konsep keilmuan, teknologi, dan seni secara dinamis melalui kegiatan pembelajaran yang menyenangkan, sesuai dengan tahapan perkembangan anak, nilai moral, karakter yang ingin dibangun, dan budaya Indonesia

\section{Memperhatikan dan melestarikan karakteristik sosial budaya}

Kurikulum mempertimbangkan lingkungan fisik dan budaya kedalam proses pembelajaran untuk membangun kesesuaian antarapengalaman yang sudah dimiliki anak dengan pengalaman baru untuk membentuk konsep baru tentang Layanan kesehatan dan gizi terutama ditujukan untuk membantu pertumbuhan anak. Layanan perlindungan ditujukan untuk memberi dukungan kondisi dan lingkungan yang nyaman dan aman, yaitu bebas dari kecemasan, tekanan dan rasa takut. Untuk melaksanakan layanan HolistikIntegratif tersebut, Satuan PAUD harus bekerjasama antara lain dengan puskesmas, posyandu, bina keluarga balita (BKB), dan Komisi Pelayanan dan Perlindungan Anak Indonesia (KPPAI).

\section{METODE}

Berdasarkan dengan permasalahan maka peneliti menggunakan pendekatan kualitatif. Pendekatan kualitatif adalah sebuah pendekatan penelitian yang diselenggarakan dalam setting alamiah, memerankan peniliti sebagai instrumen pengumpul data, menggunakan analisis induktif, dan berfokus pada makna menurut perspektif partisipan (Moedzakir,2010:1). Fokus dari penelitian ini adalah Problematika implementasi kurikulum 2013 pada lembaga PAUD, hal ini yang menjadi dasar digunakannya pendekatan kualitatif disamping itu juga bahwa peneliti tidak hanya mengungkap peristiwa namun juga dapat mengungkap nilai tersembunyi di balik peristiwa.

Pengumpulan data penelitian kualitatif menuntut peran peneliti sebagai instrumen, Peneliti bertindak sebagai instrumen kunci dan pengumpul data, oleh karena itu kehadiran peneliti di lapangan mutlak diperlukan. (Moedzakir 2010:2). Kedudukan peneliti dalam kualitatif adalah sebagai perencana, pelaksana, pengumpul data, penganalisis, penafsir data dan akhirnya sebagai pelapor hasil penelitian (Moleong 2004:21).

Penelitian ini di laksanakan pada beberapa lembaga PAUD di kec. Kamal, pemilihannya secara acak diambil 20 lembaga PAUD sebagai tempat penelitian.

Data yang dikumpulkan adalah data yang berkaitan pada fokus penelitian Problematika implementasi kurikulum 2013, selebihnya adalah data tambahan seperti dokumen baik yang tercetak maupun yang terekam, foto - foto, sumber tertulis. Sumber data dalam penelitian ini bersumber dari data manusia dan data non manusia. Data yang bersumber dari manusia yang berupa ucapan dan tindakan diperoleh melalui wawancara dan pengamatan langsung.

\section{Prosedur Pengumpulan Data}

Dalam pengumpulan data ini peneliti menggunanakan metode observasi langsung,wawancara mendalam, tinjauan dokumen (Moedzakir, 2010:8).

1. Observasi Langsung

2. Dokumentasi 


\section{Analisis Data}

Penelitian ini menggunakan teknik analisis data yang cocok adalah teknik analisis interaktif yang dikemukakan oleh Miles dan Huberman (1994). Proses analisis data tersebut dikemukakan sebagai berikut :

\section{Pengumpulan data (data Collection)}

2. Reduksi data (data reduction)

3. Sajian data (data display)

4. Penarikan simpulan atau verifikasi (Conclusion:drawing/Verification)

5. Pengecekan keabsahan data

Tahap-Tahap Penelitian dalam penelitian ini ada beberapa kegiatan yang dilakukan peneliti antara lain:

1. Tahap Pra Penelitian

2. Tahap Penyelanggaraan Penelitian

3. Tahap Pasca Penelitian

\section{HASIL DAN PEMBAHASAN}

Kurikulum adalah seperangkat rencana dan pengaturan mengenai tujuan, isi dan bahan pelajaran serta cara yang digunakan sebagai pedoman penyelenggaraan kegiatan pembelajaran untuk mencapai tujuan pendidikan tertentu (Undang-undang Nomor 20 tahun 2003 tentang Sistem Pendidikan Nasional, Bab I Pasal 1 angka 19)

Kurikulum Tingkat Satuan Pendidikan (KTSP) untuk PAUD adalah kurikulum operasional yang dikembangkan dan dilaksanakan sesuai dengan karakteristik satuan PAUD. Artinya, kurikulum ini dibuat oleh satuan pendidikan disesuaikan dengan karakteristik satuan PAUD seperti keadaan lingkungan, peserta didik, pendidik, sarana dan prasarana, biaya, dan nilai-nilai yang mendasari, serta program yang akan dilakukan oleh satuan PAUD.

Di kecamatan Bululawang dalam pelaksanaan pembelajarannya masih belum banyak yang menerapkan kurikulum K13 dari 24 lembaga PAUD tidak lebih dari separunya yang sudah melaksanakan kurikulum 2013, dikarenakan kurangnya pemahan tentang kurikulum 2013.

Berdasarkan analisis yang dilakukan dalam pelaksanaan kurikullum 2013 beberapa guru sudah banyak yang mendengaar tentang K13 namun, mereka tidak memahami bagaimana pelaksanaannya, ada beberapa guru yang dusah pernah dikirim mengikuti pelatihan penyusunan Kurikulum baik yang di lakukan tingkat kabupaten ataupun tingkat provinsi, namun tetap saja dalam pelaksanaannya di daerah atau di lembaga masih susah untuk di laksanakan.

Pelaksanaan kurikulum 2013 mengalami kendala baik Sumber daya alamnya ataupun juga Sumber Daya Manusianya. Masih banyak sekolah yang keurangan anak didik, masih banyak guru yang belum mengasah kreatifitasnya untuk melaksanakan kurikulum 2013. Para pendidik menggunakan Lembar Kerja Anak ( LKA) untuk kegiatan pembelajaran setiap harinya, Karena mereka beranggapan praktis dan cepat. Tanpa mereka sadari hal ini yang akan mematikan kreatifitas mereka sendiri. Jika kreatifitas dalam diri seseaorang sudah tidak bias berkembang maka yang terjadi adalah pembejaran yang monoton dan membosankan. Padahal seharusnya pembelajaran untuk anak usia dini harus berorientasi bermain dan belajar, berpusat pada anak.

Pelaksanaan kurikulum 2013 di beberapa sekolah tidak dapat terlaksana juga di karenakan prasarana yang belum memadahi, mau tidak mau pembelajaran k13 membutuhkan sarana yang sesuai dengan materi, mengingat hal tersebut banyak pendidik akhirnya terpatahkan semangatnya dalam melaksnakan kegiatan pembelajaran di kelas. Permasalahan lain adalah tuntutan orang tua yang mengharapkan anak mereka setelah masuk tingkat Sekolah Dasar sudah bisa membaca dan menulis, dan hal ini yang paling susah dilakukan pendidik ketika anak hanya dianggap masuk sekolah PAUD hanya bermain, padahal dalam konsep bermain telah ada konsep membaca, menulis dan berhitung ketika hal itu dilaksanakan dengan benar oleh pendidik. 


\section{SIMPULAN}

Tingkat kreativitas pendidik di sekolah sangat berpengaruh besar pada hasil belajar anak, dan anak akan berhasil dalam pendidikannya ketigka guru di sekolah mampu mengembangkan bakat dan minat anak didik sesuai dengan kemampuannya. Secara generik, pengembangan kreativitas anak dapat dilakukan dengan menggunakan berbagai pengkondisian atau membangun iklim yang memicu berkembangnya kemampuan berpikir dan berkarya. Landasannya adalah menguasai pengetahuan dan menerapkan ilmu pengetahuan dalam bentuk keterampilan terbaik. Dalam pelaksanaan kurikulum 2013 yang paling berperan besar adalah pendidik, tingkat kreativitas pendidik akan mempengaruhi pelaksaan pembelajaran yang menyenangkan untuk anak.

\section{Saran}

Semakin kreatif guru dalam menyampaikan materi dalam proses pembelajaran, akan semakin mudah peserta didik menerima materi yang disampaikan, di situlah letak keberhasilan pelaksanaan kurikulum 2013 di lembaga PAUD.

\section{DAFTAR PUSTAKA}

Dirjen PAUDNI. Kerangka Dasar dan Struktur Kurikulum 2013 PAUD, 2014. Kementrian Pendidikan dan Kebudayaan RI.

Moleong, J Lexy 2006. Metode Penelitian Kualitatif. Bandung: PT. Remaja Rosdakarya

Moedzakir, D. 2010. Desain dan Metode Penelitian Kualitatif. Malang: Fakultas Ilmu Pandidikan Universitas Negeri Malang.

Undang-undang Republik Indonesia Nomor 20 Tahun 2003 Tentang Sisdiknas dan Peraturan Pemerintah Republik Indonesia Tahun 2010 Tentang Penyelenggaraan pendidikan Serta Wajib Belajar. 2010. Bandung: Citra Umbara. 